\title{
AMPHIBIANS
}

\section{NORTHERN LEOPARD FROGS IN A GOLF COURSE WATER HAZARD}

MARTIN BAILEY, 1021833 Coteau Avenue, Weyburn, SK. E-mail: cmbb@sasktel.net

The Weyburn Golf Course ninth hole is a challenge. You must loft your ball over a deep pond fringed on both sides with cattails. Farther back from the water, Water Smartweed (Polygonum amphibium) and tall grasses grow before you reach the manicured greens. Unbeknownst to the majority of golfers, even those whose golf balls ended up in the water, the pond hosted an estimated 600 to 800 Northern Leopard Frogs on July 21, 2003.

The Northern Leopard Frog (Rana pipiens) is characterized by "conspicuous dark dorsal spots bordered by light coloured rings...and prominent light-coloured dorsolateral folds... Adults range from 50 to $100 \mathrm{~mm}$ in length." 5 The frogs at the ninth hole were, on average, $45 \mathrm{~mm}$ in size from the tip of their snouts to their vents on July 21 . This mass of leopard frogs was probably sub-adults, for young, newly transformed from the tadpole stage, range in size from 24 to $26 \mathrm{~mm}^{4}$

The Committee on the Status of Endangered Wildlife in Canada classifies the prairie population of the Northern Leopard

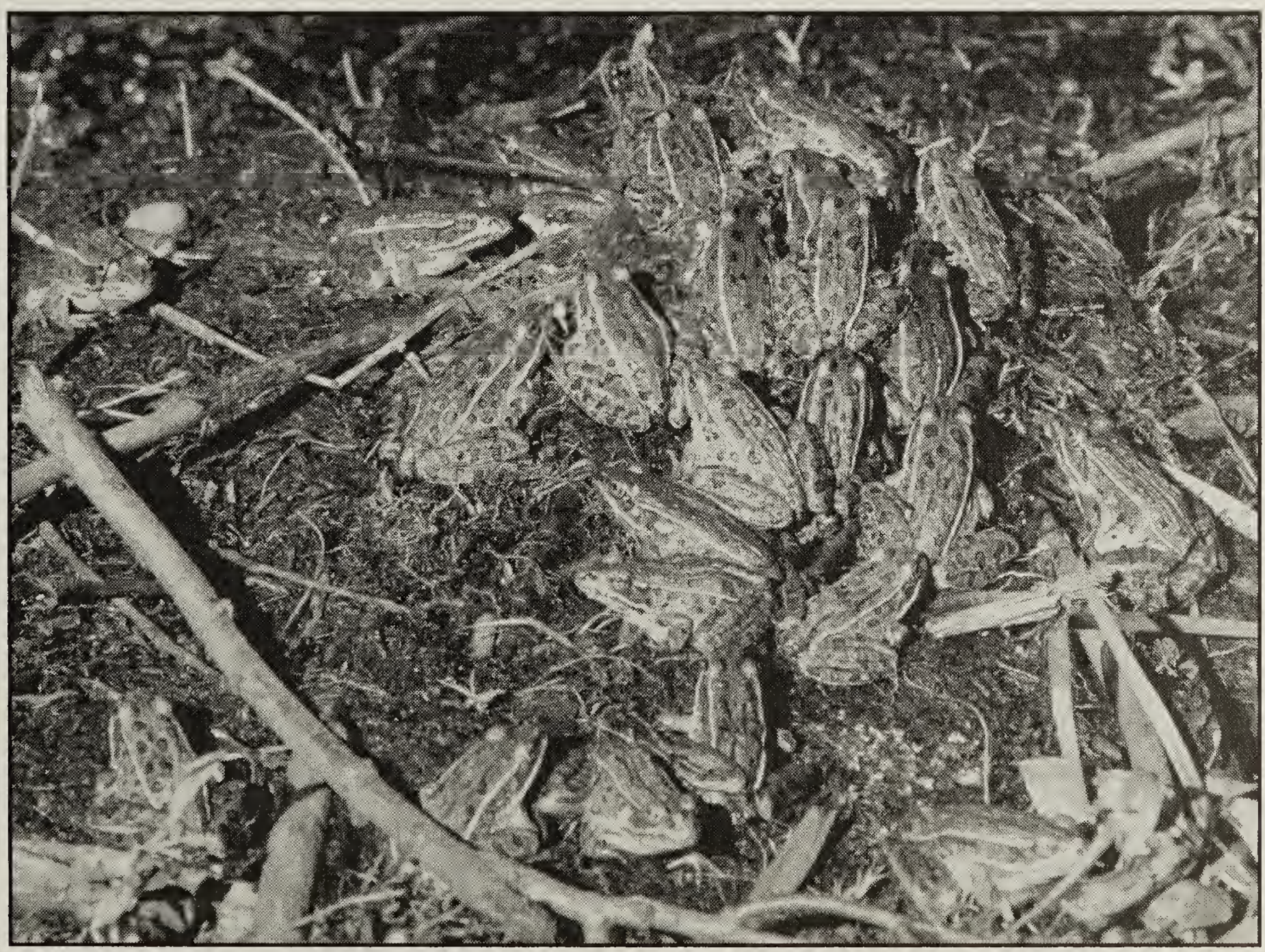


Frog as a species of Special Concern, i.e. a species that is particularly sensitive to human activities or natural events. While it is not in danger of being extirpated in the Prairies Provinces, its numbers have certainly gone down over the years. In Saskatchewan its status is "secure": populations are widespread but isolated. 5

Every spring in Weyburn, we have heard the cacophony of Boreal Chorus Frogs but rarely the "low guttural snore" of the Northern Leopard Frog. ${ }^{1}$ Irruptions of these frogs do happen (Jim Duncan, pers. comm.) and this sudden profusion of leopard frogs where they have not been seen in recent memory is not unique. The flooding in spring 2003 of "the rough" around the ninth hole created a shallow temporary pond that lacked fish which could have preyed upon the developing frogs. This flooded area with the nearby cattails which provided anchors for egg masses, created an ideal breeding site for Northern Leopard Frogs. ${ }^{2,3,5}$

Weyburn Golf Course, built in 1981, covers 2 square $\mathrm{km}$ of land. It sits between Rinfret Brook, which rises in the Tatagwa Marsh southwest of Weyburn, and the Souris River, which begins between Worcester and Talmage, and flows northwest before doubling back through Weyburn and ambling on to Estevan. The natural flow of water through the golf course is from Rinfret Brook to the Souris River. However, because of the culverts, sluice gates, and the dictates of the Saskatchewan Water Authority, the flow of water from Rinfret Brook through the golf course to the Souris River does not always occur. Water from Rinfret Brook can, and does, pass by the golf course's southern border on its way to the Souris without coming into the Golf Course. On the other hand, water from an arm of the Souris River sometimes overflows the sluice gate at the ninth hole water hazard situated at the northern extremity of the golf course.
When the frogs were first noticed on July 15 , the dominant water plant of the ninth hole water hazard was Star Duckweed (Lemna trisulia). The frogs were the green morph of the Northern Leopard Frog and would easily go unnoticed as they sat in the pale green duckweed. Coon's-tail (Ceratophyllum demersum), another water plant, was also evident in the pond at the same time but was overrun by Star Duckweed as summer went on.

The water hazard is separated from an adjacent water body by a causeway with a culvert positioned at least two metres above the bottom of the pond. The culvert was above the waterline in July 2003.

The adjacent second body of water snakes the length of the golf course. Its east bank is steep and no frogs were seen in this water body except near the causeway where cattails and pondweed (Potamogeton sp.) grow. In the pondweed patch, a smaller number (less than 100) 45mm-long Northern Leopard Frogs were found on July 15, the same day that frogs were first seen in the Star Duckweed on the other side of the causeway.

Great Bulrush (Scirpus validus) is common along the shorelines of some of the golf course ponds. No frogs were found amongst this large and imposing marsh plant. The bulrush dominated its immediate environment, and the mud between each great bulrush stalk was an empty space. This is in keeping with observations in British Columbia where Canary Grass (Phalaris arundinacea) formed a monoculture that affected frog movement and foraging. ${ }^{2}$ Other water plants noted in the golf course ponds at the end of July were northern water milfoil, (Myriophyllum exalbescens) and Richardson's Pondweed, (Potamogeton richardsonii).

A number of factors made Weyburn's golf course a good habitat for frogs. Deep 
permanent ponds and inlets, and shallow enclosed water bodies for overwintering, breeding and development are all within a kilometre of each other, in or surrounding the golf course. ${ }^{3}$ The human traffic near the water bodies, while not in conflict with the frogs, keeps away avian predators such as Great Blue Heron and Belted Kingfisher. Though herbicides and fertilizers are used on the golf course's greens, they are only applied after the ground is aerated. So, in the case of the ninth hole green, situated a hundred yards from the water hazard, the likelihood of damaging levels of herbicides or fertilizers seeping down to where the frogs were located appears to be low.

\section{Acknowledgements}

Without John Whitell's initial observations of the Northern Leopard
Frogs, this article would not have been possible. After his initial discovery, he and I then conducted this survey together.

1. BEHLER, J.L. and F.W. KING, Eds.1979. The Audubon Society Field Guide to North American Reptiles and Amphibians. Alfred A. Knopf, New York.

2. KENDELL, K. 2003. Status of the Northern Leopard Frog in Alberta. Alberta Wildlife Status. Report No. 9. Alberta Environment.

3. MCALLISTER, K.R., W.P. LEONARD, and D.W. HAYS. 1999. Washington State Status Report for the Northern Leopard Frog. Washington State Department of Fish \& Wildlife.

4. NOVA SCOTIA MUSEUM WEB SITE. http:// museum.gov.ns.ca/mnh/nature/frogs/northd.htm

5. SPECIES AT RISK WEB SITE. Www.speciesatrisk.gc.ca
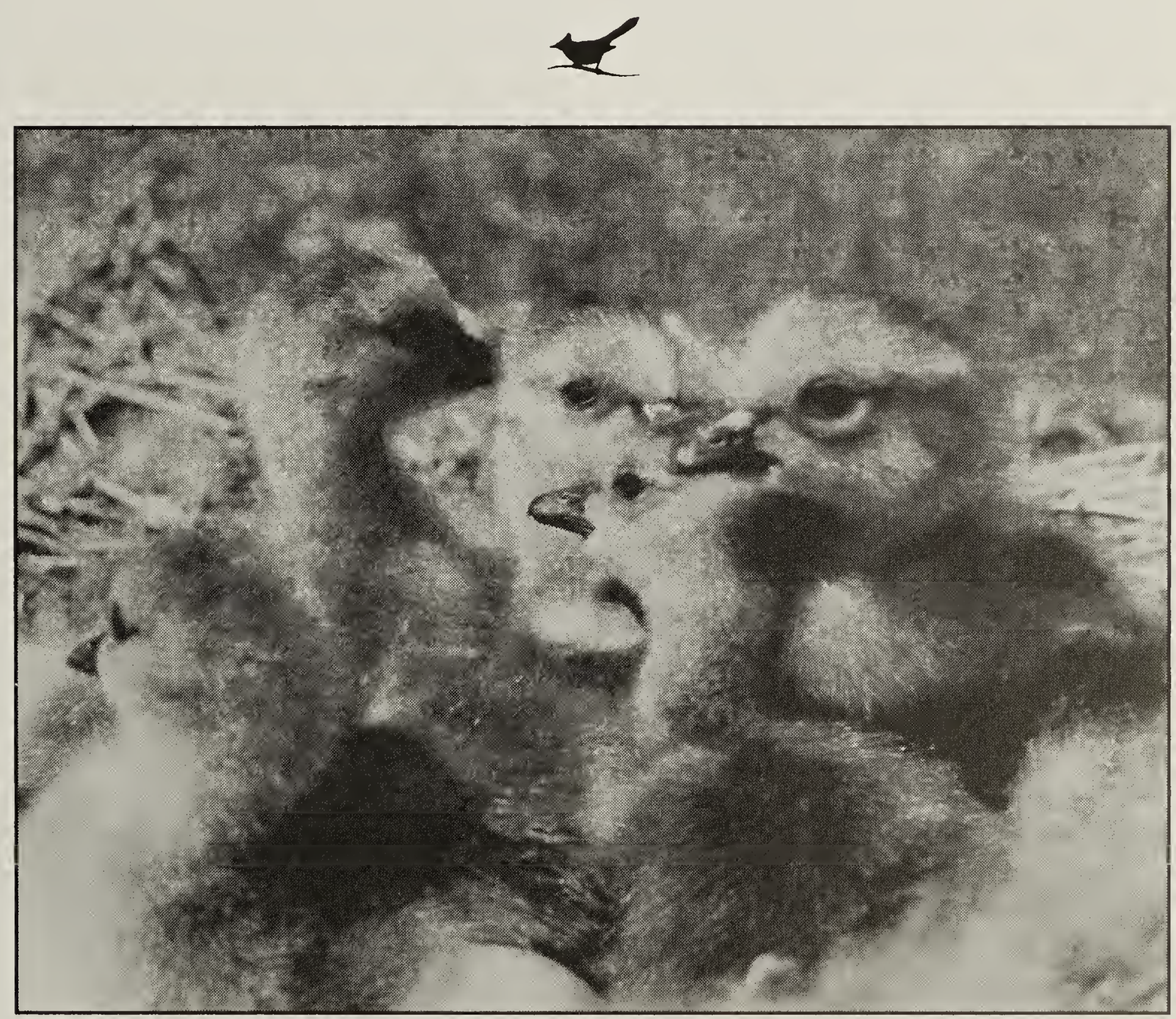